\title{
THE DORSAL HOLOCRINE SKIN GLAND OF THE KANGAROO RAT (DIPODOMYS) ${ }^{1}$
}

\author{
W. B. QUAY \\ Department of Anatomy, Medical School, and Division of Mammals, \\ Museum of Zoology, University of Michigan \\ EIGHT FIGURES \\ INTRODUCTION
}

The dorsal, holocrine, skin gland of the kangaroo rat (Dipodomys) is an area of modified and enlarged sebaceous gland units in the mid-dorsal skin over the arch of the back. It has been found in all examined species of the genus and its gross seasonal and sexual variations in size and secretory activity, differing from species to species, have been described (Quay, '53). The present report describes the microscopic structure and composition of the gland, as it appears in the species agilis, spectabilis, merriami, ordi, deserti, and panamintinus. The taxonomic arrangement follows that of Setzer ('49).

\section{MATERIAL AND METHODS}

The specimens studied and their data are listed in table 1 . The techniques used may for convenience be divided into histological and histochemical categories and are as follows.

\section{Histological techniques}

(1) Ehrlich's acid hematoxylin and eosin; (2) Heidenhain's iron hematoxylin (Bensley and Bensley, '38) without counterstain; (3) Taenzer-Unna acid orcein method for

${ }^{1}$ I wish to thank W. H. Burt and E. T. Hooper of the Museum of Zoology for facilities and for the opportunity of examining specimens in their care, and Robert Smith for aiding in the collection of specimens. 


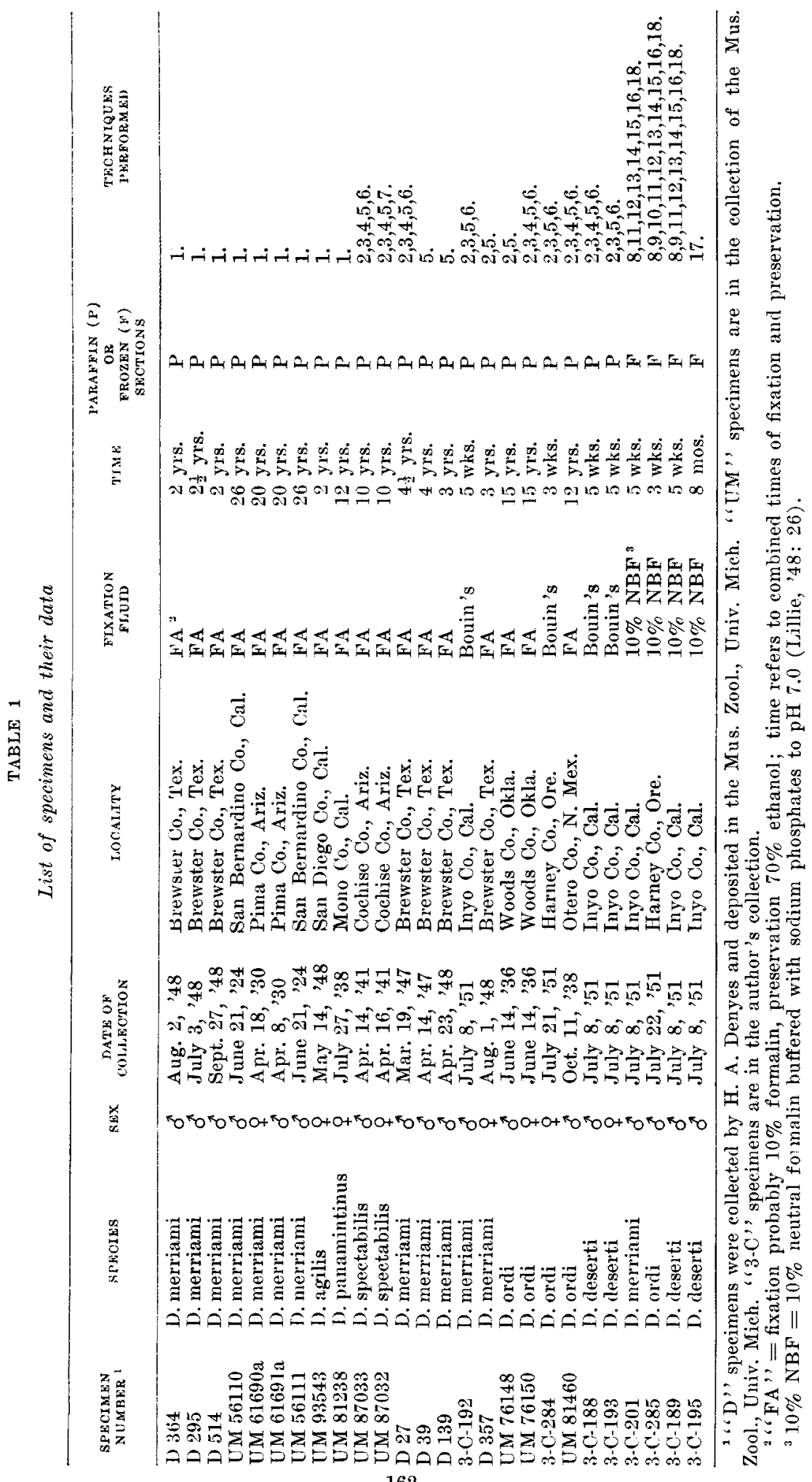


elastic fibers with azure A counterstain (Lillie, '48) ; (4) Foot method for silver impregnation of reticulum (Bensley and Bensley, '38) with hematoxylin and eosin or azure A counterstain; (5) Heidenhain's modification of Mallory's connective tissue stain (Azan) (Bensley and Bensley, '38); and (6) buffered azure eosinate method (Lillie, '48: 83).

\section{Histochemical techniques}

(7) Romieu reaction for tryptophane in proteins (Glick, 49); (8) Berg ninhydrin test for a-amino acid groups (Glick, '49); (9) Mallory's iodine reaction for amyloid as amended by Lillie ('48) and with a preliminary wash in $1 \%$ acetic acid; (10) Masson's section method (Lillie, '48) for demonstrating' the argentaffin reaction; (11)) 2,4-dinitrophenlhydrazine reaction (Lillie, '48); (12) Nile blue A after 10\% NBF fixation and using saturated and $1 \%$ saturated solutions of Nile blue A (otherwise as in Cain, '47); (13) Sudan black (Lillie, '48); (14) Oil red O (Lillie, '48); (15) Oil blue N (Lillie, '48); (16) Windaus digitonin reaction (Lillie, '48); (17) Baker's acid hematein test ('46, '47) with and without previous pyridine extraction; (18) polarized, ultraviolet and visible light.

\section{DEVELOPMENT AND MORPHOLOGY}

The sebaceous glands budding from hair follicles in the dorsal gland area enlarge when the dorsal gland is becoming active. At the center of the dorsal gland area are the sebaceous glands of greatest development. At the periphery are those of least development, showing the transition from unmodified to modified glands (plate 1:3). In most species each group of 6 to 7 hair follicles and associated unmodified sebaceous glands is replaced by one greatly enlarged sebaceous gland (plate $1: 3$ ). The enlarged gland units are at first ovoid and slightly lobulated. In all species except spectabilis the continued enlargement of the gland acini occurs primarily by proliferation from the basal cells along the bottom of the gland, imparting a high conical shape to the 
gland unit and limiting the lobulation to its base (plate 1: $2,3)$. In these species the lobules are short and pressed together, so that the interlobular septa are very thin. In the species spectabilis, the exception, the enlargement of the gland units oceurs by proliferation from the basal cells on all sides of the sebaceous parenchyma and by buds from the sides of the ducts. The result is a complex of lobes and lobules radiating in all directions from a central duct or ducts. The lobules are frequently long and are usually not pressed together (fig. 1).

In all species except spectabilis the basal cells at the bottom of the gland unit proliferate to form a hard pillar of secretion which extends intact through the neck of the gland and out to the surface (plate 1:2,7). In spectabilis the secretion breaks down within the duct to form a soft oily material (fig. 1). In the examination of dried skins of Dipodomys for dorsal glands (Quay, '53) the hard pillars of secretion were seen in all species except spectabilis. In this species the dorsal gland was detectable as an area of excessively oily and matted fur (see Vorhies and Taylor, '22:6).

As the amount of sebaceous tissue increases in the dorsal gland area, the skin becomes thicker. In merriami the unmodified skin with inactive hair follicles adjacent to the dorsal gland area is $.20-.30 \mathrm{~mm}$ in thickness. In the center of the most active dorsal gland areas the skin thickness is 1.30 $\mathrm{mm}$. This increase is primarily in the dermis. The undesquamated layer of the epidermis is $4-7 \mu$ thick in unmodified areas and increases to $70 \mu$ in the center of active dorsal gland areas in merriami.

The more densely packed the sebaceous tissue in the dorsal gland area, the fewer the hair follicles. What few hair follicles are visible may or may not be active. Usually when one of the dorsal gland area hair follicles is active in hair formation, nearly all are; however, none of the follicles lying outside the dorsal gland area may be active. Or when the follicles in the unmodified skin outside the dorsal gland area are active, none of those within the area are so. 'Thus 

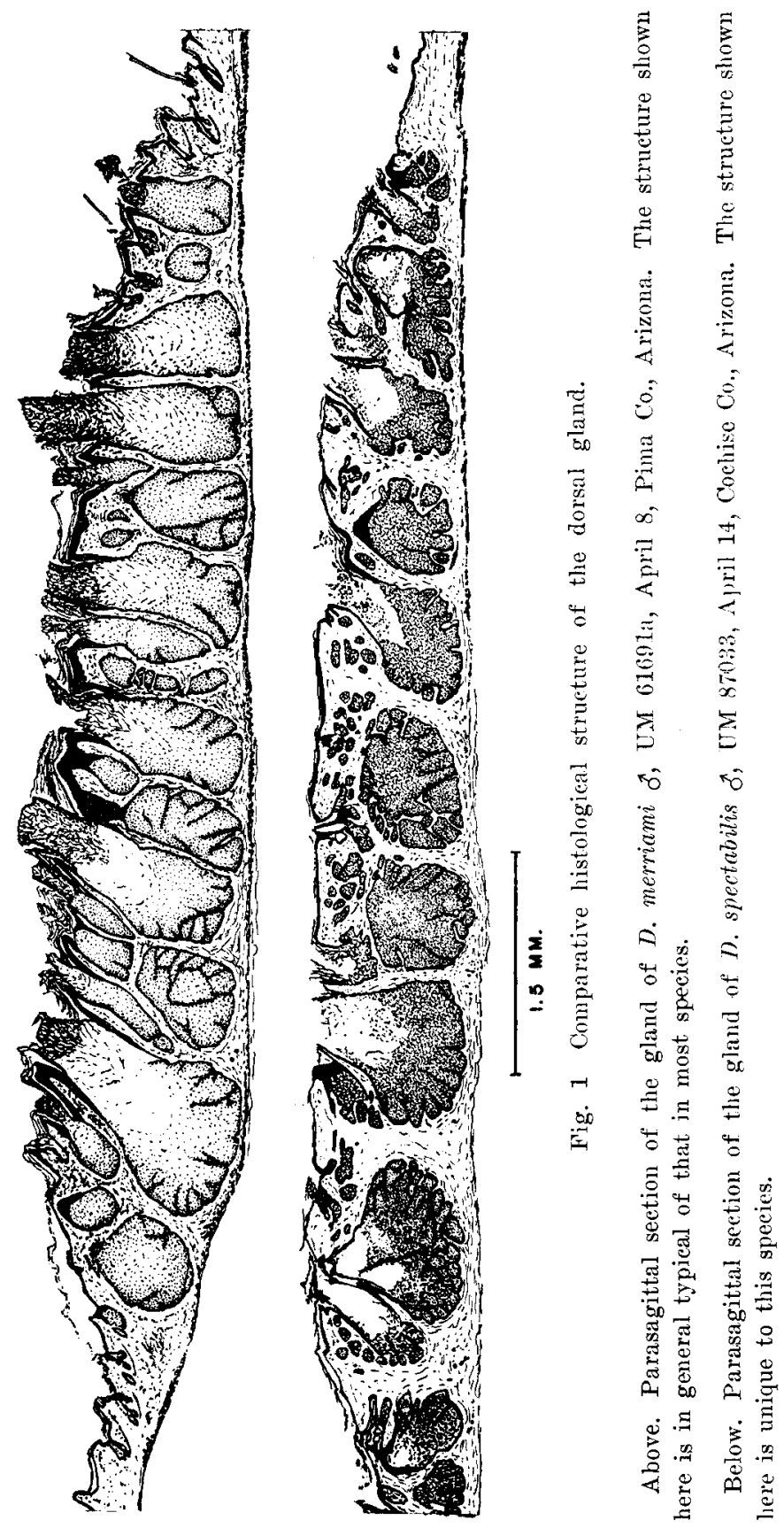
the activity of the hair follicles within the glandular area is frequently out of phase with the activity of the follicles in the surrounding unmodified areas. This was apparent in the dried skins examined (Quay, '53) as well as in histological preparations.

The only sexual differences noted in the histology of the gland area are quantitative ones which require statistically significant samples for adequate description. These are not yet available.

\section{HISTOLOGY}

\section{Parenchyma}

The ducts of the glands are composed of stratified squamous epithelium which is continuous with that of the epidermis. In both the upper part of the gland necks and in the epidermis of the dorsal gland area the granular layer is distinct and continuous, and the cornified layer is thick. In the epidermis outside the glandular area the granular cells are exceedingly rare and the cornified layer is thin; the single or double layer of cuboidal basal cells is the primary one seen. Deeper within the necks of the gland units of the dorsal gland area the granular and cornified zones become thinner and finally are lacking and the basal cells become squamous and overlapping. In this region there may be 4 to 5 cell layers, composed of squamous cells, the superficial ones paler than the basal ones below. Deeper yet, the duct epithelium is reduced to a single layer of squamous cells continuous with the basal cells of the sebaceous acini. In glands that have been actively secreting for a longer time, as shown by higher pillars of secretion, the stratified and thicker type of duct epithelium extends farther toward the base of the gland.

In most respects the sebaceous cells of the Dipodomys dorsal gland units are similar to those of unmodified sebaceous glands in this and other rodents. However, they are distinguished in histological preparations by two features: (1) the presence of a very large vesicle within each 
cell, and (2) resistant eell walls and intercellular material which tend to hold the secretion mass together in a column. These two features are most highly developed in $D$. desert $i$ (plate 1: 7,8). The tall pillars of sebaceous cells described in the flank gland of the water rat (Vrtis, '30) resemble the secretion pillars in the Dipodomys dorsal gland, but differ from them in the fact that they are composed of immature cells rather than highly modified dead cells. Similarly there is some resemblance between the tall cell columns in the femoral organ of Lacerta (Tolg, '05) and those in the Dipodomys dorsal gland.

\section{Stroma}

A diffuse network of delicate elastic fibers permeates the dermis, even into the interlobular septa of the glands. In the upper third of the dermis between glands the elastic fibers are enlarged and more numerous, especially in the glandular areas of greater activity and depth. In this region many elastic fibers may be followed into the crevices between the basal epithelial cells of epidermis and gland necks. In the tips of the dermal partitions in $D$. deserti the elastic fibers are very densely woven and are circularly arranged around the necks of individual glands. In most specimens elastic fibers are abundant between and beneath the muscle fibers of the subjacent panniculus dorsalis (of Howell, '32).

The Foot silver impregnation blackens delicate fibers which delimit the glands and the sides of the interlobular septa. Elsewhere such fibers are diffusely seattered, as also are the thicker fibers of collagenous type.

Mast cells are found throughout the dermis between the glands. They are especially abundant in the upper part of the dermis where they are associated with abundant small blood vessels. A few mast cells occur in the interlobular septa of the glands.

In sections treated with lipid colorants, dermal fat cells are shown to be practically nonexistent in the active dorsal 


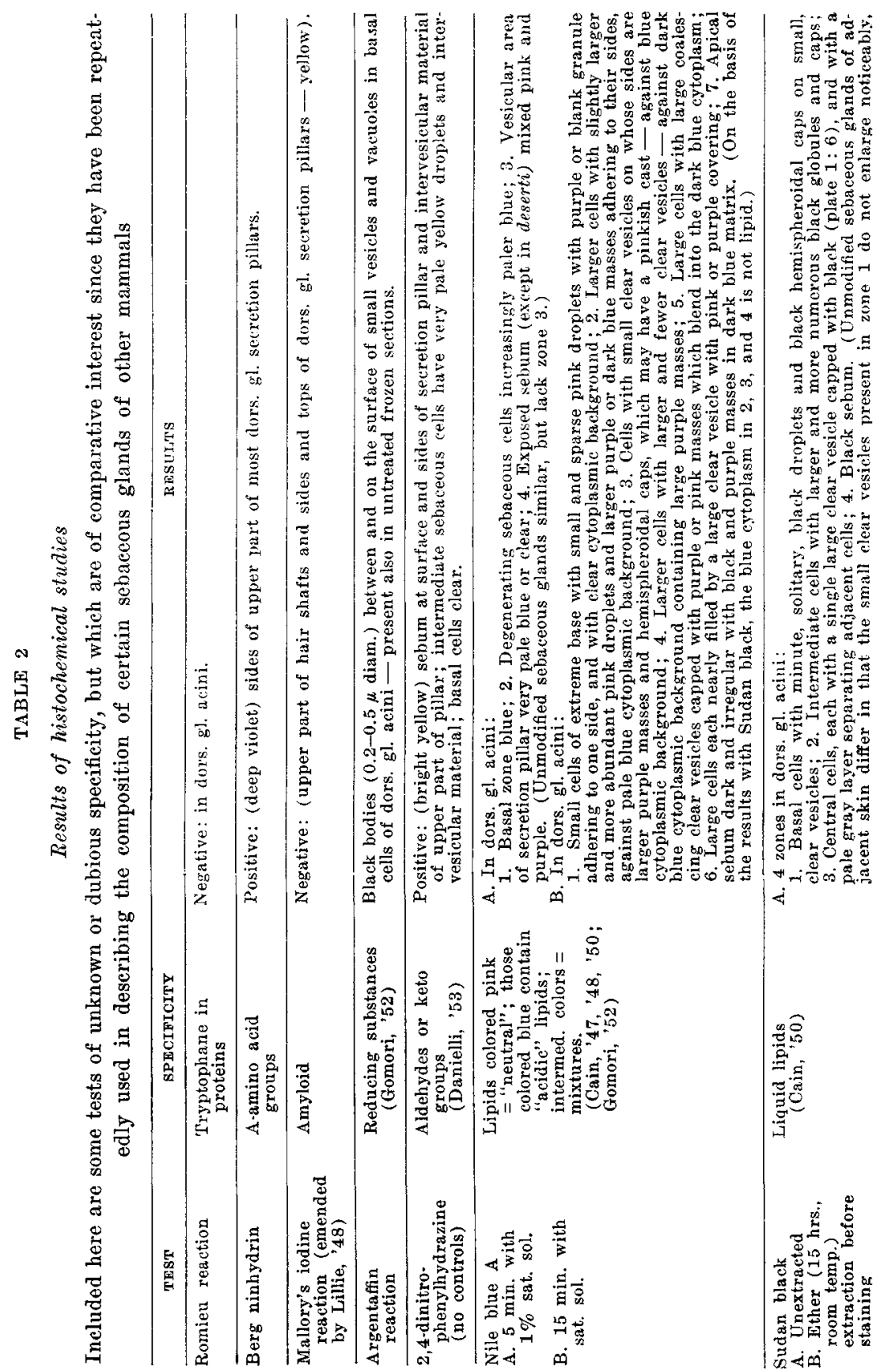




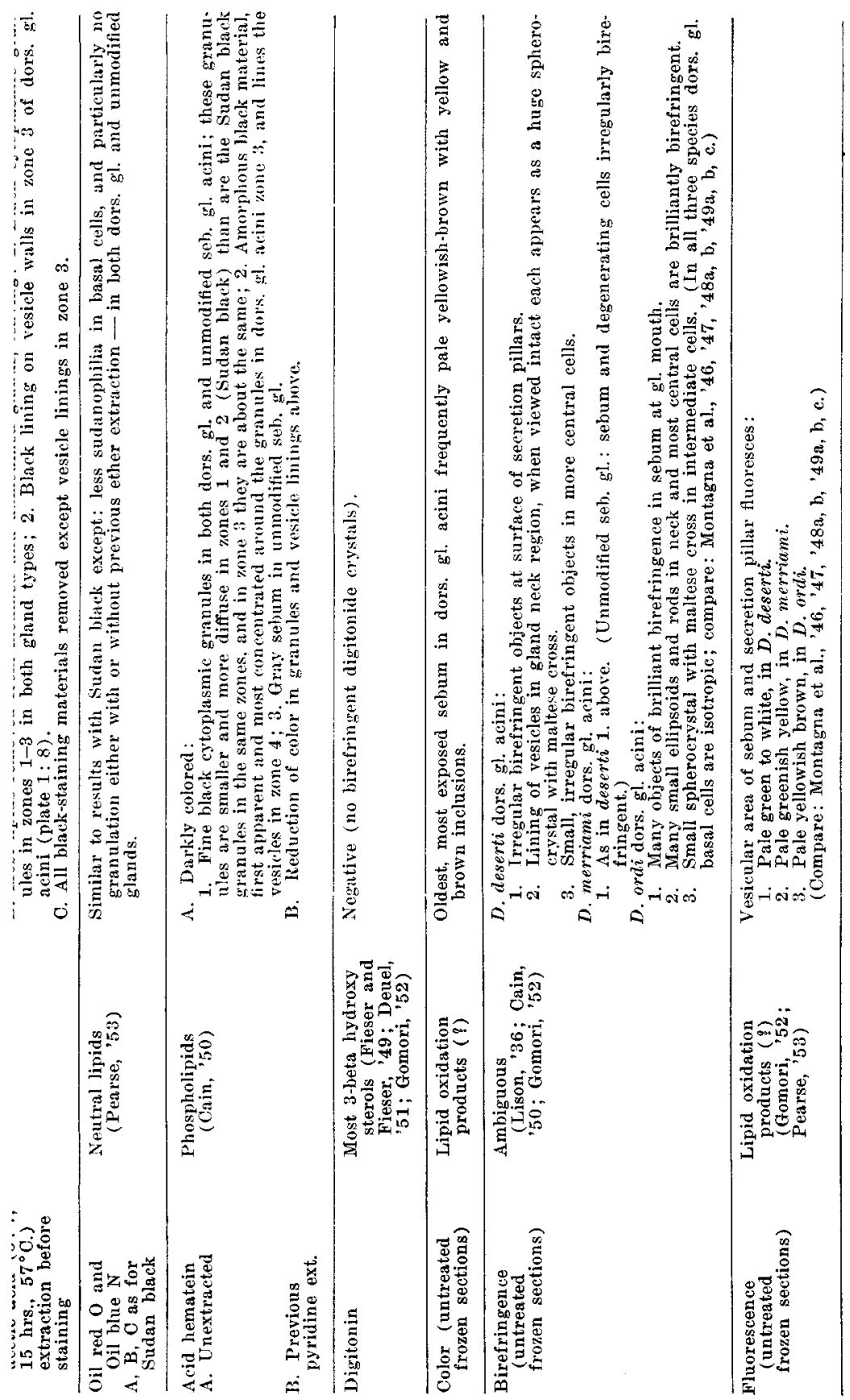


gland areas, but are abundant in the lower levels of the dermis in the adjacent unmodified skin.

Large and highly branched dermal melanophores are abundant and are nearly restricted to the upper part of the dermal partitions between the necks of dorsal gland units.

\section{Histochemistry}

The results of the histochemical studies of the dorsal gland acini are presented in table 2 . The correlations and interpretations of the results are included in the following discussion.

\section{DISCUSSION}

\section{Cytological constituents and their changes}

Granules in the dorsal gland acinar cells are probably the first visible structures related to secretion formation in these cells. The granules are difficult to remove with solvents; only xylene-glacial acteic acid mixture was completely successful in this regard. However, at least the outer covering of the granules contains lipid and is apparently acidic. In the more central cells particularly, this acidic lipid material contains phospholipids. Similar granules have been described by Montagna et al. ('48a, b ; '49a, b, c) using similar' techniques on the sebaceous glands of other genera and Orders. Granular mitochondria in sebaceous cells studied by other workers with different techniques have a similar appearance and position (Nicolas, Regaud and Favre, '12; Ludford, '25) and recent knowledge of mitochondrial structure and composition (Bourne, '51) is in harmony with this tentative correlation.

Associated with the granules are: (1) "neutral" lipid droplets or globules, and (2) "acidic" lipid caps or coverings. The granules lie on the surface of the neutral droplets and are embedded in the acidic caps. In older or more central acinar cells the size of the two lipid structures increases until they finally fuse. The "neutral" lipid droplets are so-called 
because of their pink color after Nile blue treatment. Similar pink droplets stained in this manner have been reported in the sebaceous glands of other mammals by Montagna et al. ('47; '48a, b; '49a, b, c). The "acidic'' lipid caps or coverings are so-called because of their dark blue color after Nile blue treatment, resulting probably from the presence of fatty acids. They bear a close positional and structural similarity to structures designated as Golgi apparatus in the Meibomian gland of the cat (Bowen, '26) and in the sebaceous glands of the mouse (Mus) (Ludford, '25); however, there is some doubt concerning the true nature of the material designated as Golgi material in these two investigations (Bowen, '29: 503).

Within and at one side of each "neutral" lipid droplet a clear vesicle develops. It enlarges concurrently with the enlargement of the droplet and the "acidic" covering of the droplet. The vesicles within each cell fuse until finally there is but one within each cell. The content of the vesicles, aqueous or gaseous, is unknown and enigmatic, especially so since the excretion of waste materials by the kangaroo rat presents unique physiological problems (see Schmidt-Nielsen and Schmidt-Nielsen, '52).

As the "neutral" and "acidic" lipid materials become mixed in the central cells of the dorsal gland acini, the granules become the centers of phospholipid formation. The phospholipid is then mixed with the other lipid materials and with them lines the vesicles of the pillar of secretion.

\section{SUMMARY}

The dorsal, holocrine, skin gland, a mid-dorsal area of enlarged and modified sebaceous glands was studied in 26 kangaroo rat (Dipodomys) specimens (species: agilis, spectabilis, merriami, ordi, deserti, panamintinus). Glandular area epidermis and dermis are thickened; elastic fibers, mast cells, capillaries, and melanophores are particularly abundant in the dermal partitions between gland units. 
Observations on tests for tryptophane and a-amino acid groups in proteins, amyloid, argentaffin reaction, 2,4-dinitrophenylhydrazine reaction, "neutral" and "acidic" (Nile blue) lipids, 3- $\beta$ hydroxy sterols, phospholipids, color, birefringence, and fluorescence are presented. Sebaceous cell lipids are first apparent in relation to granules which: (1) are thinly covered with phospholipid, (2) adhere to "neutral", lipid droplets, and (3) lie in "acidic" (fatty acid) caps over the droplets. Within each droplet, a clear vesicle develops. In maturation, the "neutral" droplets, "acidic" coverings, and clear vesicles enlarge and fuse until finally within each cell there is one large, clear vesicle covered with mixed lipids. Within this lipid material a-amino acid groups, aldehydes or keto groups, and phospholipids are demonstrable. This phospholipid is first formed and is most concentrated around the granules which persist in the mixed lipid material. Resistant cell membranes cause the sebum to be excreted as a pillar, except in spectabilis. The size and characteristic features of the gland are best developed in deserti.

\section{LITERATURE CITED}

BAKer, J. R. 1946 The histochemical recognition of lipine. Quart. J. Micro. Sci., 87 : $441-471$.

1947 Further remarks on the histochemical recognition of lipine. Quart. J. Miero. Sci., 88: 463-465.

Bensley, R. R., and S. H. Bensley 1938 Handbook of Histological and Cytological Technique. University of Chicago Press, Chicago.

Borrne, G. H. 1951 Mitochondria and the Golgi complex, Chapter VI, In: Cytology and Cell Physiology. Ed. by G. H. Bourne, Oxford University Press.

BoweN, R. H. 1926 Studies on the Golgi apparatus in gland cells. Ir. Glands producing lipoidal secretions - the so-called skin glands. Quart. J. Miero. Sci., 70: 193-215.

1929 The cytology of glandular secretion. Quart. Rev. Biol., 4: 299-324, 484-519.

CAIN, A. J. 1947 The use of Nile blue in the examination of lipoids. Quart. J. Micro. Sei., 88: 383-392.

1948 A further note on Nile blue. Quart. J. Micro. Sci., 89: 429. 1950 The histochemistry of lipoids in animals. Biol. Rev. Cambridge Philos. Soc., 25: 73-112. 
DANifLI.I, J. F. 1953 Cytochemistry a Critical Approach. John Wiley and Sons, New York, Chapman and Hall, London.

DELET, H. J., JR., 1951 The Lipids their Chemistry and Biochemistry. Vol. I : Chemistry. Interscience, New York and London.

Fieser, L. F., ANd M. Fieser 1949 Natural Products Related to Phenanthrene. 3rd ed., Reinhold, New York.

Grick, D. 1949 Techniques of Histo- and Cytocliemistry, a Manual of Morphological and Quantitative Mieromethods for Inorganic, Organic and Enzyme Constituents in Biological Materials. Interscience, New York.

Gomori, G. 1952 Microscopic Histochemistry Principles and Practice. University of Chicago Press, Chicago.

Howell, A. B. 1932 The saltatorial rodent Dipodomys: the functional and comparative anatomy of its museular and osseons systems. Proc. An. Acad, Arts and Sci., 67: 377-536.

LILI1E, R. D. 1948 Histopatholigic Technic. Blakiston, Plialdelplia and Toronto.

Lison, F. 1936 Histochimie animale. Méthodes et problèmes. Gauthier-Villars, Paris.

Ludford, R. J. 1925 The eytology of tar tumours. Proc. Roy. Soe. London, Ser. B, 98: $557-577$.

Montagna, W. $1949 \mathrm{~b}$ Anisotropie lipids in the sebaceous glands of the rabbit. Anat. Rec., 104: 243-254.

$1949 \mathrm{e}$ The glands in the external auditory meatus of the cat. J. Morph., 85: 423-442.

Montagna, W., and J. B. Hamilton 1949a The sebaceous glands of the hamster. II, Some cytochemical studies in normal and experimental animals. Am. J. Anat., 84: 365-396.

Monagna, W., AND C. R. Noback 1946 The histochemistry of the preputial gland of the rat. Anat. Rec., $96: 111-128$.

1947 Histochemical observations on the sebaceous glands of the rat, Am. J. Anat., 81: 39-62.

Monirana, W., C. R. Noback and F. G. Zak $1948 \mathrm{~b}$ Pigment, lipids, and other substances in the glands of the external auditory meatus of man. Am. J. Anat., 83: 409-436.

Montagna, W., and H. F. Parks 1948a A histochemical study of the glands of the anal sac of the dog. Anat. Rec., 100: 297-318.

Nicolas, J., C. REgaud and M. Favre 1912 Sur les mitochondries des glandes sébacées de l'homme et sur la signification générale des ees organites $d u$ protoplasma. Compt. Rend. de l'Assoc. des Anat., 14th Reunion, Rennes, Bibliog. anat. Suppl., 201-205.

PEArse, A. G. E. 1953 Histochemistry Theoretical and Applied. Little, Brown and Co., Boston, J. and A. Churchill Ltd., London.

Quay, W. B. 1953 Seasonal and sexual differences in the dorsal skin gland of the kangaroo rat (Dipodomys). J. Mamm., 34: 1-14.

SCHMIDT-NIELSEN, K., AND B. SCHMIDT-NIELSEN 1952 Water metabolism of desert mammals. Physiol. Rev., 32: 135-166. 
SETzER, H. W. 1949 Subspeciation in the kangaroo rat, Dipodomys ordii. Unip. Kansas Publs. Mus. Nat. Hist., 1 (23) : 473-573.

TOLG, F. 1905 Arb. zool. Inst. 15: Wien. (Quoted from: Eggeling, H. von, Hautdrusen. In: Handbuch der vergleichenden Anatomie der Wirbeltiere. 1: 633-692.)

Vorhies, C. T., AND W. P. TAYLOR 1922 Life history of the kangaroo rat Dipodomys spectabilis spectabilis Merriam. U, S. Dept. Agrie. Bull. 1091.

VRTIS, V. 1930 Glandular organ of the flanks of the water rat, their development and changes during the breeding season. Biologicke Spisy. Acad. Veterinariae, Brno, 9 (4): 1-51.

\section{PLATE 1}

EXPLANATION OF FIGURES

2 Parasagittal section of a typical gland unit with secretion pillar. Hematoxylin and eosin. D. merriami $\delta$, UM 6169la. $\times 41$.

3 Tangential section of dorsal skin, showing transition from groups of hair follicles in unmodified skin to enlarged sebaceous glands in the dorsal gland area. Hematoxylin and cosin. D. merriami o, D $364 . \times 41$.

4 Parasagittal section of typical dorsal gland units, showing the distribution of lipids. Sudan black. D. ordi on, 3-C-285. $\times 64$.

5 Parasagittal section of dorsal skin from epidermis (above) to panniculus (below), showing size and relations of unmodified sebaceous glands colored for lipids. Sudan black. D. merriami ơ, 3-C-201. $\times 88$.

6 Basal cells (below) and maturing cells (above) from the base of a dorsa1 gland acinus colored for lipids and showing the formation of lipid-covered vesicles. Sudan black. D. deserti of, 3-C-189. $\times 272$.

7 Parasagittal section of typical dorsal gland units after 15 hour ether extraction and $5 \mathrm{~min}$. Sudan black coloring. D. deserti of, 3-C-189. $\times 34$.

8 Enlarged cells from near the base of the gland unit shown at right in figure 6, showing amorphous and granular phospholipid around the vesicles. $D$. deserti on, 3-C-189. $\times 800$. 
W. B. QUAY
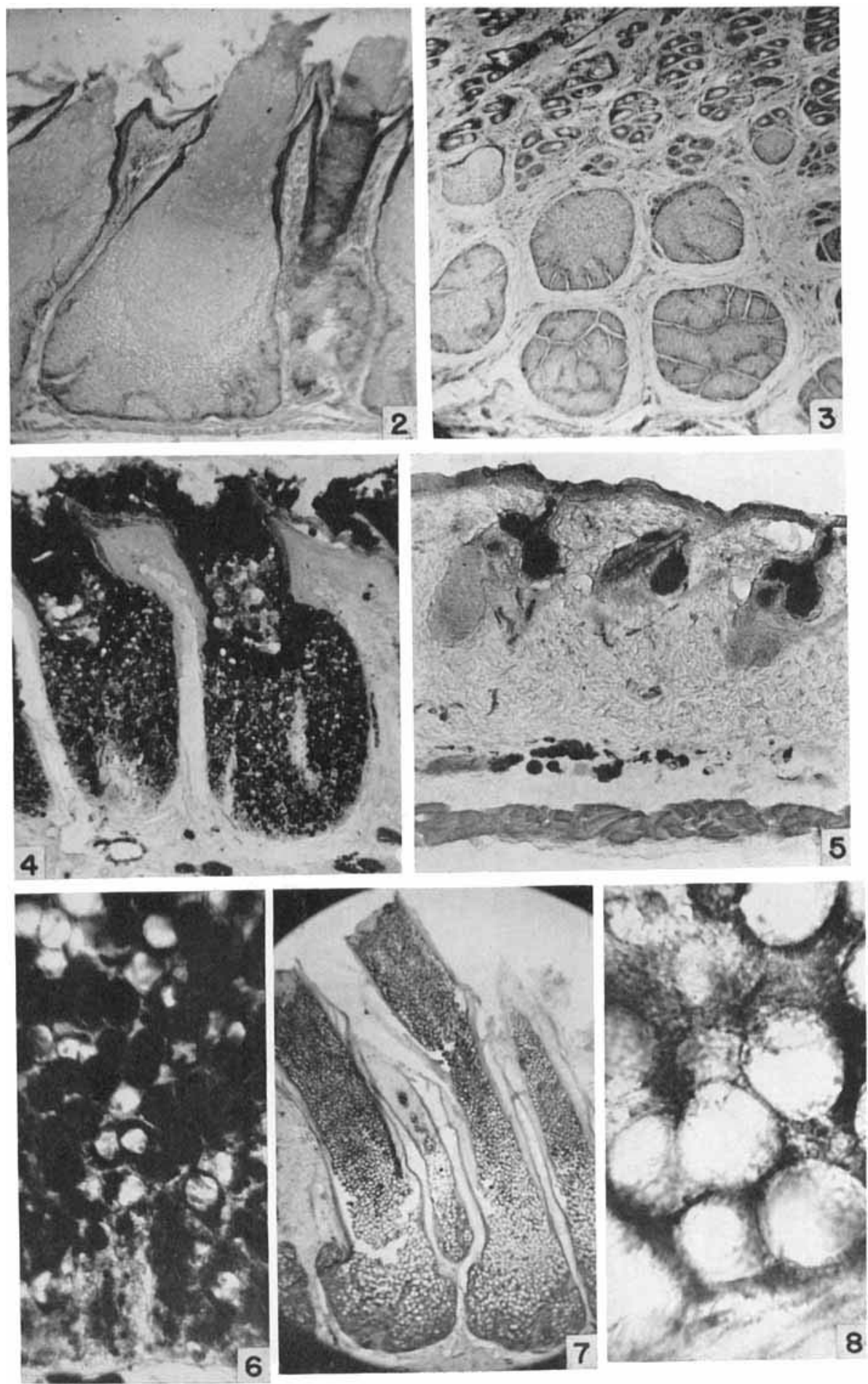